\title{
Platinum mineralization comparative characteristics of the some Far East deposits
}

\author{
Natalya Lavrik $^{1^{*}}$, Natalya Litvinova ${ }^{1}$, Tatyana Aleksandrova ${ }^{2}$, Valentina Stepanova ${ }^{1}$ and \\ Alexandra Lavrik $^{1}$ \\ ${ }^{1}$ Mining Institute of Far eastern branch of Russian Academy of Sciences, Khabarovsk, Russia. \\ ${ }^{2}$ Federal State Budgetary Educational Institution of Higher Education "St. Petersburg Mining \\ University", St. Petersburg, Russia.
}

\begin{abstract}
Annotation. In this article shown platinum mineralization comparative characteristics for three deposits: Kondoer-traditional unique deposit and other two probably alternative source of platinum: the Poperechnoe ironmanganese deposit and the Malmyzh copper-porphyry deposit. Platinoids of the Kondoer deposit are the chain $\mathrm{Pt}>>\mathrm{Ir}>\mathrm{Os}>\mathrm{Ru}=\mathrm{Rh}>\mathrm{Pd}$. The presences of platinum crystals are characteristic, there are over 50 rare and new platinoids minerals in different combinations. There are gold and silver. Platinoids from the iron-manganese ore of Poperechnoe are as $\mathrm{Pt}>>\mathrm{Rh} \approx \mathrm{Ir}>\mathrm{Ru} \approx \mathrm{Os}>\mathrm{Pd}$. A scattered dissemination of arsenide sulfate and sulfides of $\mathrm{Rh}, \mathrm{Ir}, \mathrm{Ru}$, Os are noted in the platinum. Palladium is present as impurities in gold and platinum. The gold content is different-with admixtures $\mathrm{Ag}, \mathrm{Pb}, \mathrm{Cd}, \mathrm{Fe}$. At this stage the platinoids content in oxidized ores of the Malmyzh gold-copper porphyry deposit is $\mathrm{Pt} \approx \mathrm{Pd}$. The gold is present as electrum. There is native silver cadmium.
\end{abstract}

\section{Introduction}

There is in the modern world economy a high demand for industrial metals including platinum group metals (PGE), - platinum, palladium, rhodium, iridium, osmium, and ruthenium. A meet growing needs problem in the platinum-metal raw materials became more seriously each year $[1,2]$.

The Russian Federation balance reserves are $73.8 \%$ palladium, $21.7 \%$ platinum and other platinoids slightly more than $4 \%$. Native deposits have a leading role in the reserves and production of PGE. The search for rich placer deposits of PGE is currently an actual problem [2]. Therefore, more attention is paid to the study of new ore types and alternative sources of noble metals. These include low-sulfide proper platinum-metal ores of exfoliated ultramafic-mafic intrusions, black-shale polymetallic platinum-containing ores of sedimentary complexes, nickeliferous weathering crusts, man-caused ores (waste from mining, dressing and metallurgical production) [2], iron ore formations [3]. The platinum content is studied poorly in the: fossil coals, asphaltites, porphyry ores, saline sediments, ocean formations and other.

\footnotetext{
* Corresponding author: lavrik@igd.khv.ru
} 
Although, one genetic type deposits have a differences, the article authors compared the platinum mineralization of three deposits in the Far East: the unique most studied, placer and ore deposit of the concentrically-zoned Kondoer deposit; the Poperechnoe ironmanganese deposit with noble metal mineralization; the Malmyzh a large gold-copperporphyry deposit, in whose oxidized ores the visible platinum was first isolated.

\section{Materials and research methods}

Platinum mineralization characteristics of alkali-ultrabasic Kondoer deposit (the most studied platinum source from Far East) took mainly from the basis of literary data and some of the authors' own research.

Mineralogical and technological analysis of samples for noble metals from ore-bearing and enclosing rocks of the Poperechnoe iron-manganese deposit and Malmyzh gold-copper porphyry deposits was carried out using the patented technique for the detection of noble metal mineralization, developed at MI FEB RAS.

At first, samples were crushed to $1 \mathrm{~mm}$. Then the gravitational enrichment without the use of magnetic separation, short mineralogical analysis and electron microscopy was used. Modern Fritsch equipment was using for samples preparation: jaw crusher Pulverizete 1, disk mill Pulverizette 13, ultrasonic bath for cleaning sieves Laborette 17, vibrating screen Analyzette 3. A Stemi 2000 C microscope (Germany, ZEISS) was used for short mineralogical analysis of the monofraction. The electron microscopic study of platinum and gold composition from different ores and altered rocks was carried out using a JEOL microscope (Japan) equipped with an energy dispersive X-ray analyzer JCM-6000 PLUS and a VEGA 3 LMH microscope with X-Max 80 microanalysis.

\section{Results research}

\subsection{Kondoer}

Kondoer deposit is located in the north of the Khabarovsk region in the Maya river basin and in the interfluve of her left tributaries Omni and Maimakan.

The geological structure of the Kondoer concentric-zone ultrabasic deposit (one of the largest on the Aldan Shield) has been described and known many times, although many aspects continue to be debatable [4, 5 and ect.]. The region is formed the Archean foundation, Proterozoic platform cover and intrusive rocks of Paleozoic and Mesozoic age [6]. The central part of stock is formed by platinum-bearing dunites and dunite-pegmatites with segregations of chromospinelides. After dunite the olivine-diopside metasomatites zone followed and then the ring of clinopyroxenites, which include by intrusions (J3-K1) monzonitoids, syenites, gabbroids, kosvits, alkaline diorites [7]. Platinoids ore manifestations are concentrated in ultramafites as accessory submicroscopic sizes in chromospinelides and chromites. The main platinum is in placers with the size from fractions of $\mathrm{mm}$ to nuggets weighing $1-3 \mathrm{~kg}$. Stocks of placer platinum are over 90 tons. The average content of platinoids in placers is up 0.2 to $2 \mathrm{~g} / \mathrm{m} 3$, and to $60-80 \mathrm{~g} / \mathrm{m} 3$ in the richest areas [4]. The main mineral of deposit is iridic isoferroplatinum containing $\mathrm{Pb}, \mathrm{Cu}$ and platinoids impurities.

There were found over 50 minerals of platinoids, gold and silver in the placer. Some from them are rare and new, for example, bordnikovit $\mathrm{Pd} 4 \mathrm{Cu} 3 \mathrm{Zn}$, konderite $\mathrm{Cu} 3 \mathrm{~Pb}(\mathrm{Rh}, \mathrm{Pt}$, Ir) $8 \mathrm{~S} 16$, native $\mathrm{Ru}, \mathrm{RuOs}[8,9]$. Isoferroplatinum forms are diverse: well-cut crystals of regular cubic and octahedral form, twins; teardrops, xenomorphic formations and "porous" 
dendritic. Heavy concentrated platinum differs in color (tin-white, lead-gray, dark graphite, brown-red) and it's characterized by a magnetic susceptibility (Fig. 1).

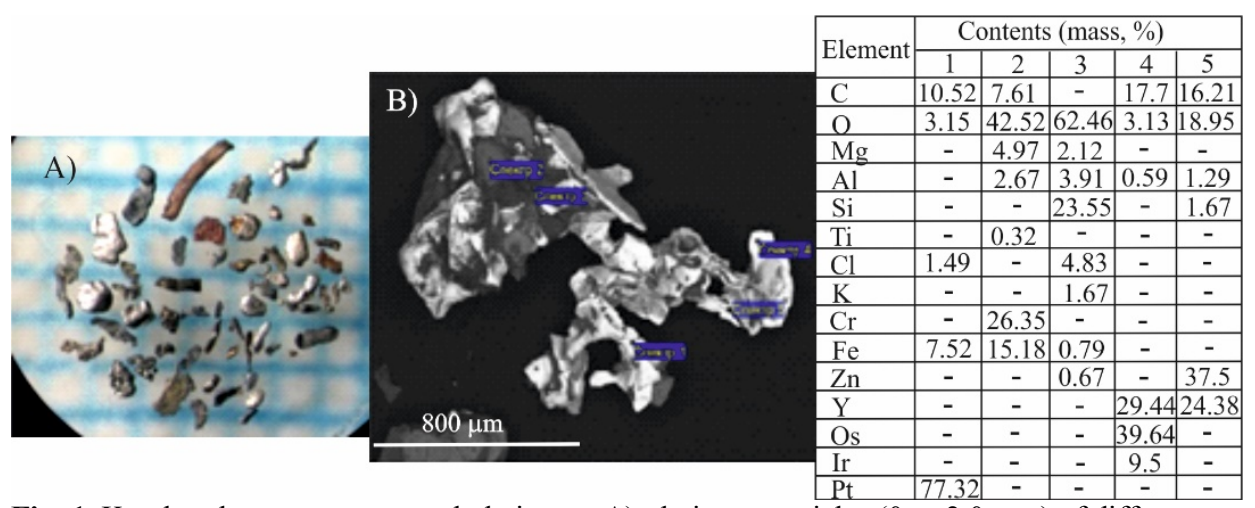

Fig. 1. Kondoer heavy concentrated platinum : A) platinum particles $(0, \mathrm{n}-2.0 \mathrm{~mm})$ of different morphology and properties; B) platinum grains of unusual shape and complex composition in intergrowth with chromites and other minerals.

"Crystalline nuggets" of platinum often is covered "Golden shirt". On the mineralogical research it's tin (0.05-1.0 mm) membrane compounds of gold-copper and of platinumpalladium. Membranes of gold compounds on the majority of non-rolled crystals are endogenous [10]. Xenomorphic and dendritic grains of platinum may contain sprouts of magnetite, limonite, chromite, olivine and other minerals (Figure 1).

The distribution of platinoids in zonal massifs is characterized by a series: $\mathrm{Pt}>>\mathrm{Ir}>\mathrm{Os}>\mathrm{Ru}=\mathrm{Rh}>\mathrm{Pd}[11]$.

There is characteristic presence the gold and silver along with platinum and palladium, which have a second role. The gold is bright yellow in plate-shaped and flattened forms. The part of grains is brownish in limonite shirt.

There are found native $\mathrm{Cu}, \mathrm{Sn}, \mathrm{Pb}, \mathrm{Ni}, \mathrm{Fe}, \mathrm{Sb}, \mathrm{Bi}$ [10]. The main minerals of heavy fraction are presented as follows: pyroxene, magnetite, titanomagnetite, limonite, chromite, olivine; are found: apatite, almandine and pyrope, amphibole, tourmaline, zircon, pyrite, marcasite, galena, chalcopyrite, rutile, ilmenite, sphene, chrome diopside and spinel.

\subsection{Poperechnoe}

It is well known that iron ore deposits are one of the most important potential unconventional sources of precious metals [12]. The Poperechnoe iron-manganese deposit (South Khingan ore cluster) locating in Jewish autonomous region in additional to the main ores contains precious metals: gold and silver, platinum and palladium. A lot of specialists have been carrying out in the past years the study of the noble metal mineralization of the South Khingan ore cluster [13-17].

The ore-bearing structure extends in the submeridional direction for $54 \mathrm{~km}$ and a width of 6-8 km. The ore cluster and adjoining territory are composed of limestone, carbonate rocks of dolomite composition and shales of the Upper Proterozoic Khingan sequence, as well as Lower Cambrian limestones of the londokovo suite and a variegated complex of rocks of the Kimkan layer. There are fluidites (fluidno-explosive formations) within the Poperechnoe deposit that contain the ore deposit and they are structural and materially complex rocks $[16,17]$. Steeply sloping ore formations have been studied to a depth of up to $400 \mathrm{~m}$. Manganese content is $20.4 \%$. Its stocks are estimated at 5116 thousand tons in categories B $+\mathrm{C} 1$. Iron stocks were not counted [17]. 
Platinum is in all ore types and in the enclosing carbonate breccias. The main part of platinum grains is (up to $0.4-0.5 \mathrm{~mm}$ ) light gray and angular-lumpy forms, there are flattened, somewhat deformed, cubic crystals, platelets; have a high magnetic susceptibility. The platinum content is variable. In general, it is isoferroplatinum $(\mathrm{Pt} 3 \mathrm{Fe})$ with a variable content of impurities $\mathrm{Cu}, \mathrm{Pd}, \mathrm{Sn}, \mathrm{Ni}, \mathrm{Co}, \mathrm{Cr}, \mathrm{V}$. There are inclusion of well-formed crystals $(2-20 \mu \mathrm{m})$ in some isoferroplatinum grains as follows: sulphoarsenides of platinumides of complex composition such as hollingworthite ( $\mathrm{Rh}, \mathrm{Ir}, \mathrm{Pt}, \mathrm{Ru}, \mathrm{Fe}$ ) AsS-platarsite PtAsSirisite (Ir, Rh, Os) AsS; Erlichmanite, rutheniridosmin (Os, Ir, Ru), tetraferroplatinum with enstatite are noted (Fig. 2). Platinoids contents of the Poperechnoe iron-manganese deposit can be as by a chain: $\mathrm{Pt}>\mathrm{Rh} \approx \mathrm{Ir}>\mathrm{Ru} \approx \mathrm{Os}>\mathrm{Pd}$.

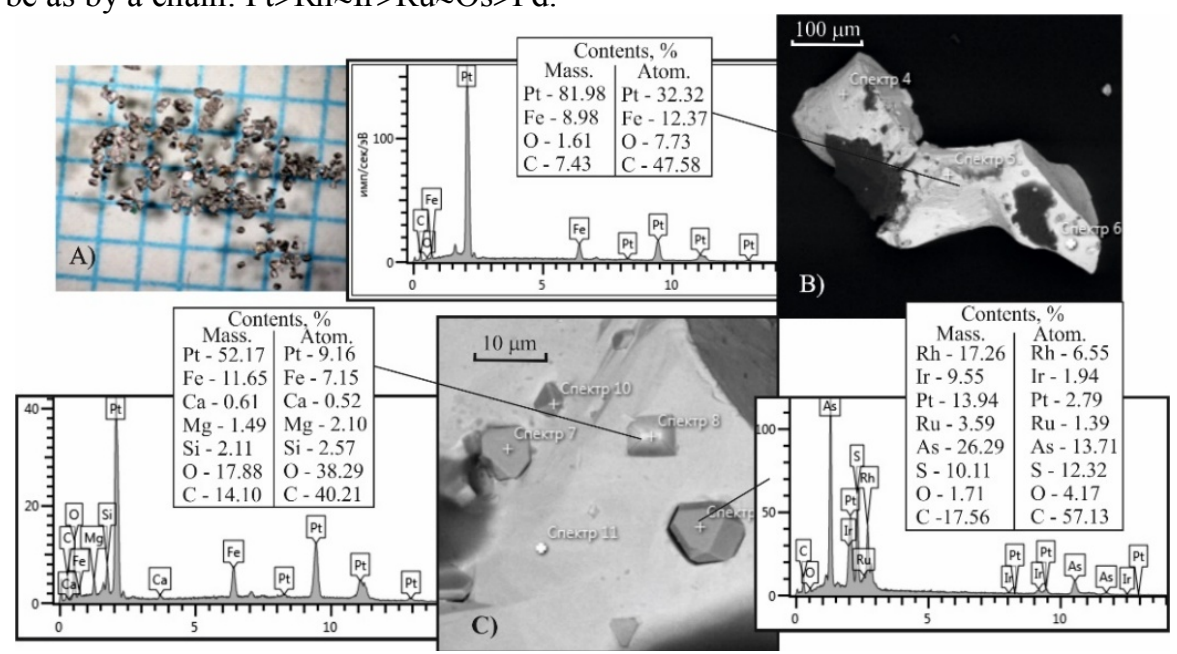

Fig. 2. Platinum from the Poperechnoe iron-manganese: A) mineralogical analysis; B) cranked grain of isoferroplatinum with inclusions of minerals of platinoids; C) crystals of cholinhuortite, tetraferroplatinum, iridosmin and other minerals of platinoids in the grain of isoferroplatinum.

There are weight grains of gold $(0.025-0.5 \mathrm{~mm})$ from ores and host rocks in additional to platinum. The gold of light yellow with strong shine has lumpy form, sometimes with elements of a cut of a cube. Its composition is variable from pure gold to electrum and with impurities $-\mathrm{Cu}, \mathrm{Pd}, \mathrm{Fe}, \mathrm{Pb}, \mathrm{Cd}$. There are in the paragenetic association as follows: quartz, pyroxene, actinolite, siderite, gypsum, almandine, iron and manganese oxides and carbonates, and feldspars. At the preliminary re-calculation iron-manganese ores of Poperechnoe deposit may contain platinum from 0.22 to $3.6 \mathrm{~g} / \mathrm{t}$, gold from 0.45 to $0.79 \mathrm{~g} / \mathrm{t}$.

\subsection{Malmyzh}

Malmyzh copper-porphyry deposits are the main sources of $\mathrm{Cu}, \mathrm{Mo}, \mathrm{Au}, \mathrm{Ag}, \mathrm{Sn}, \mathrm{Re}, \mathrm{W}$. They also contain associated: In, Pt, Pd and Se. Deposits have a low content but evenly distributed copper and a presence of associated impurities [18]. The problems solution of the genesis this deposits and metals source in ores is remain rather contradictory [19, 20].

The large Malmyzh gold-copper-porphyry deposit is located in the Khabarovsk region on the border of the Nanaisk and Amur administrative districts. There are some places of different degrees of study. The geological structure of the Malmyzh is sedimentary terrigenous deposits of the Lower and Upper Cretaceous age with Upper Cretaceous intrusions and diorite-granodiorite dikes [21]. 
The extensive fields of secondary quartzites and quartz-sericite metasomatites developed on terrigenous and Late Cretaceous intrusive rocks of moderately acidic and average composition are shown on maps. There are 7 long linear quartz stockworks.

At the last geological data of EMX Royalty Corporation [22] in the northwestern part of the Svoboda area of the Malmyzh gold-copper-porphyry deposit was discovered diatreme (depth $650-850 \mathrm{~m}$ ) composed predominantly by magmatogen-hydrothermal breccias [22].

The total source potential is no less than 10 million tons of copper and 500 tons of gold. Metals average content is $\mathrm{Cu}-0,34 \% ; \mathrm{Au}-0,19 \mathrm{~g} / \mathrm{t}$. The primary ore mineralization is presented by nests, dissemination and veins of magnetite, pyrite, and chalcopyrite. Bornite, chalcosine, sphalerite, pyrrhotite, galena, very rarely molybdenite, friable ores are in a much smaller amount. The native gold with $\mathrm{Ag}$ and $\mathrm{Cu}$ impurities is in chalcopyrite, magnetite and pyrite as very small formations (3-5 $\mu \mathrm{m})$. The silver is established as an impurity in bornite, chalcocite and with gold, tellurium, selenium and sulfur compounds There are palladium minerals [21, 23].

In 2017 MI FEB RAS together the Far Eastern Geological Institute FEB RAS and LLC "Amur Minerals" began work on the study of gold-copper-porphyry ores of the Malmyzh deposit (Svoboda district).

As a result of mineralogical and technological studies of oxidized ores from Svoboda district, the visible weight grains of platinum, gold, silver cadmium and diamonds were first identified along with characteristic ore minerals. Their origin in the samples is not unambiguous [24]. Oxidized ores are intensively limonitized and clay-diorite porphyrites. The estimated copper content in the sample is $0.09 \%$, gold $-0.52 \mathrm{~g} / \mathrm{t}$.

There are 2 grains of platinum $(0.06 \mathrm{mg})$, their form is an elongated flattened shape, similar to smoothed crystals (Figure 3, A), light gray with a matte surface. It contains an impurity of Fe up to 5\%. Pyrrhotite and baddeleyite $\mathrm{ZrO} 2(1-3 \mu \mathrm{m})$ are singly in the nests.

One grain $(0.1 \mathrm{~mm})$ of iron-platinum-zirconium intermetallic (flattened cuboctahedron) is a light, almost white with metallic sheen (Fig. 3, B). The approximate composition is FePt3Zr6. At this stage of studies platinoids content can be characterized as of $\mathrm{Pt} \approx \mathrm{Pd}$.

The weighted light yellow gold has a dimension in the range of 0.1-0.7 mm. The cold content is electrum with silver mass up to $17-26 \%$. Occasionally there are argentite and galena sprouts (up to 20-50 microns) and impurity of lead up to $6 \%$. Native silver cadmium occurs.

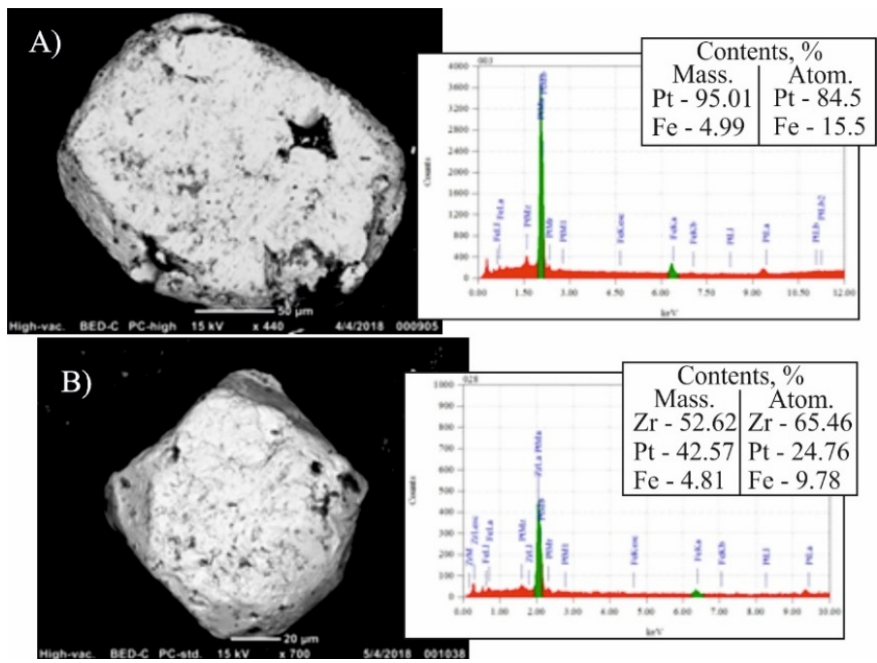

Fig. 3. Crystals of ferruginous platinum (A) and intermetallic FePt3Zr6 (B) from oxidized ores of the Malmyzh gold-copper porphyry deposit (Svoboda district) with electron microscopy. 
Crystals of greenish diamonds of $25 \mu \mathrm{m}$ to $0.4 \mathrm{~mm}$ in various form were also found in the oxidized ores. Some from them have a crust of tenardite and they contain N and Al. The origin of diamonds needs in additional research

As well the native copper, zinc, aluminum, zircon, arsenopyrite, jarosite, hematite, covellite, bornite, chalcocite, digenite, azurite and malachite are in the paragenetic association with platinum.

\section{Conclusions}

The Kondoer traditional unique deposit of alluvial platinum is formed within the alkalineultramafic massif of the zonal type. Alluvial platinum mineralization is fairly large, down to nuggets. Indigenous platinum mineralization is dispersed fine-impregnation. It is characteristically the presence of all elements of the platinum group as well as gold and silver. Kondoer platinum is iridic isoferroplatinum with $\mathrm{Cu}$ and $\mathrm{Pb}$ impurities, which can contain light and heavy platinum minerals inclusions, gold and silver minerals (over 50 rare minerals of noble metals in various combinations). The platinoids content is characterized by series: $\mathrm{Pt}>>\mathrm{Ir}>\mathrm{Os}>\mathrm{Ru}=\mathrm{Rh}>\mathrm{Pd}$.

The Poperechnoe iron-manganese deposit is an alternative source of precious metals. The platinum of this deposit is isoferroplatinum with $\mathrm{Cu}, \mathrm{Pd}, \mathrm{Sn}, \mathrm{Ni} \mathrm{Co}, \mathrm{C}$ rand $\mathrm{V}$ impurities. There are scattered inclusions of sulfides, sulfoarsenides $\mathrm{Rh}, \mathrm{Ir}, \mathrm{Ru}$ and $\mathrm{Os}$ in the platinum. Palladium is found as the gold and platinum impurities. The platinoids series from ores of the Poperechnoe is: $\mathrm{Pt}>>\mathrm{Rh} \approx \mathrm{Ir}>\mathrm{Ru} \approx \mathrm{Os}>\mathrm{Pd}$. Rhodium predominates here unlike Kondoer.

The Malmyzh gold-copper porphyry deposit also is a potential alternative platinum source. The platinum content of the deposit is poorly studied. Palladium minerals, as well as iron platinum and intermetallic $\mathrm{FePt}_{3} \mathrm{Zr}_{6}$ from the oxidized ores of the Svoboda district have been identified. At the moment platinoids content can be characterized as $\mathrm{Pt} \approx \mathrm{Pd}$.

Thus, by the noble metal mineralization content and characteristic paragenetic associations developed deposits of different genesis we can say that the platinum sources are high-temperature deep.

The Poperechnoe and Malmyzh deposits have good prospects as alternative platinum sources in complex processing.

The work was carried out through financial support of the project of the Presidium of the FEB RAS No. 18-2-015.

\section{References}

1. N.P. Laverov, V.V. Distler, Ore Deposits geology, 45/4, 291-304 (2003).

2. L.I. Gurskaya, D.A. Dodin, Regional Geology and Metallogeny, 64, 84-93 (2015)

3. N.M. Chernyshov, S.P. Molotkov, O.G. Reznikova, Bulletin of Voronezh State University. University. Series: Geology, 2, 137-162 (2003).

4. D.A. Dodin, N.M. Chernyshov, O.I. Cherednikov, Metallogeniya platinoids of large regions of Russia, 302 (2001).

5. L.B. Sushkin, Pacific Geology, 14/5, 97-102 (1995).

6. G.V. Andreev, Kondoer deposit of ultrabasic and alkaline rocks, 75 (1987)

7. L.V. Eirish, V.A. Stepanov, Pacific Geology. 21/3, 27-39 (2002).

8. A.S. Mekhonshin, T.B. Kolotilina, News of the Siberian Branch of Earth Sciences of the Russian Academy of Natural Sciences, 2 (41), 97-106 (2012).

9. A.V. Lennikov, V.V. Ivanov, RA Octyaborskiy, Deep-seated magmatism, its sources und plumes, 191-227 (2008) 
10. L.J. Cabry, J.H.G. Laflamme, The mineralogical Record, 28, 97-106 (1997).

11. V.G. Lazarenkov, A.G. Marchenko, I.V. Talovina, Geochemistry of platinum elements (1996).

12. D.A. Dodin, N.M. Chernyshov, V.A. Yatskevich, Platinum-metal deposits of Russia (2000).

13. A.M. Zhirnov, GIAB, 5/12, 115-120, (2009).

14. VG Nevstruev, N.V. Berdnikov, B.G. Saksin, V.I. Usikov, Pacific Geology, 6/6, 102111 (2015).

15. A.I. Khanchuk, I.Yu. Rasskazov, V.G. Kryukov, N.M. Litvinova, B.G. Saksin, DAN, 470/6, 1-3 (2016).

16. N.V. Berdnikov, V.G. Nevstruev, B.G. Saksin, Pacific Geology, 36/6, 43-57. (2017).

17. V.G. Kryukov, N.M. Litvinova, N.A. Lavrik, V.F. Stepanova, Enrichment of ores, 4/370, 42-48. (2017).

18. D.S. Bukhanova, P.Yu. Plechov, Vestnik KRAUNTS. Earth sciences, № 2/34, 61-70. (2017)

19. M. Tarkian, D.G. Eliopoulos, M. Economoueliopoulos, Neues jahrbuch fur mineralogie-monatshefte, 12, 529-537. (1991).

20. He Xiaohu, Zhong Hong, Zhu Weiguang, Acta geologica sinica-english edition, 88/4, 1288-1309. (2014).

21. D.S. Bukhanova, Geological processes in the conditions of subduction, collision and slip of lithospheric plates, 396. (2016).

22. Electronic resource: www.emxroyalty.com. News Release 2018.

23. 24. V.V. Ivanov, V.V. Kononov, E.K. Ignatiev, Tectonics, Deep Structure and Mineralization of the East of Asia, 258-261. (2013).

24. V.A. Pakhomova, D.G. Fedoseev, V.B. Tishkina, S.Yu. Buravleva, Gemmology, 113122. (2015). 